\title{
Critical Analysis of Educational Development during Muslim Era in Spain
}

\author{
Hafiza Sumaiya Amin ${ }^{1} \&$ Dr. Jawaid Siddiqui ${ }^{2}$ \\ ${ }^{1}$ Research Scholar, Hamdard Institute of Education and Social Sciences (HIESS),Hamdard University Karachi, \\ Pakistan \\ ${ }^{2}$ Research Supervisor \& Dean, Faculty of Humanities and Social Sciences,Hamdard University Karachi, \\ Pakistan
}

\begin{abstract}
Muslims in Spain had superb development in all field of life, especially in education. Muslim of Spain did great inventions in sciences, established educational institutions, set up libraries; translation in Arabic from Latin had been made, and played an important part in field of education and invention. The imperial patronage of education raised the standard of learning and literacy to a high level in Spain. But what was the reason that Muslims worked for the development of education. Did they think that education is their religious obligation? Does Islam emphasis on acquiring of knowledge? In analysis this was the teachings of Quran and Sunna that they had gone to explore the world. In Islam there is an emphasis on value of knowledge. There have a number of verses in which Allah impressed upon men that acquiring of knowledge is must for Muslims. So, Muslim has thought that acquiring knowledge and imparting of learning is one of their religious obligations, Muslims followed the principles of Islam, and this is the Muslim's philosophy of Islam that they gained knowledge about each and every thing in this universe which ALLAH has created. They knew that without the practicing of Islam, they could not achieve their goals. In this paper effort is being made to point out that, because of Islamic philosophy of acquiring knowledge, Muslims did superb advancement in the field of education during their era is Spain. But eventually when they turned their backs to the principles and teachings of Islam, they had gone through their path and fell in lavishness and luxuries. In fact they went too far away from the principles and practices of Islam. Eventually, they lost all grace and glory.
\end{abstract}

Key Words: Critically, Analysis, Development, Educational

\section{Introduction}

Education, whether conducted in a formal or no formal way, always involves the process of teaching, delivering, or transmitting knowledge to the learner. Islam is a religion where education gets higher level in their belief. In Holy Quran there have a number of places where Allah has clearly impressed upon man that observe and study the nature of the universe. As observation and study are the bases of science and knowledge. Allah has clearly impressed upon men that, He through His bestowed on men the gift of knowledge.

In present study, effort is being made to point out that because of Islamic philosophy of acquiring knowledge; Muslims did superb advancement in the field of education and sciences during their era in Spain. Thisresearch is basically a content analysis, for this purpose verses have been given from Quran, and quotes have been given from hadith. Related literature was also helpful for this study. Considering this, the present study has been designed to evaluate the educational development of Muslims during their era in Spain by finding answers of the following questions;

1. What was the reason that Muslims worked for the development of education?

2. Did they think that education is their religious obligation?

3. Does Islam emphasis on acquiring of knowledge?

For finding answers of these questions some verses can be extracted from Quran, and then evaluate with references of reliable books. In Quran Allah has clearly impressed upon man about gaining knowledge of this universe.

In Quran Allah says;

Sūratul Alaq verses 1-5:

'Proclaim (Read)! (Iqra') in the name of God thy Lord and Cherisher, who created man, out of a clot. Proclaim! And Lord is most Bountiful, He Who taught ('Allama) the use of the Pen (Qalam), and taught ('Allama) man what he did not know'. 
The word 'Iqra' was first reveled by Allah to his last messenger in the cave of Hira, where HazratJibraiel came to him and said Iqra (read), and Muhammad (pbuh) replied I can't read, but angel repeat this for three times. After that Muhammad repeat what Jibraiel recite (Ka'bah, Rifyal, et al., n.d., p. 2). In this conversation it concludes that this was a process of teaching, where Muhammad was a learner and Jibraiel was a teacher. Therefore it is really important to deliver message of Allah to all human beings. For Muslims accept that Allah is only one, and worship him with proper understanding. Secondly what He makes for man in this universe that should be researchable and what He created for all human, so as to protect the faith and strengthen his religion in the light of the Holy Quran (King Abdul Aziz University, 1977).

At another place where Allah says;

In Suratul Zumur verse No: 9 not know?!"

"Can the learned and the illiterate be of the same status? Are those, who know, equal with those who

It is fact that most of the verses which relate to acquiring knowledge were revealed in Makkah, and Prophet appointed Sahaba for writing the revelations. In short Quran is never tired of advising man to use his brain and exercise the faculty of their mind. Reading, reflecting, reciting, researching, and studying are the important elements in education.

That's why Holy Prophet was also forced Muslim to learn and read. When after hijrat to Madina Prophet constructed a first mosque which was also a school of Muslims. This platform used to be called "Suffa". (M. Hamiuddin, Vol. 1). After the battle of Badar when Muslim had won, the Prophet fixed the ransom to the prisoners of Kuffar-e- Makkah that they should teach the Muslim children, and they will allow to free.

In the light of Holy Prophet Commands:

"Seek knowledge, even if it be in Cin (China)".

"The scholar and the students are the best of human beings"

"For every disease, Allah has given a cure"

It is clear that Prophet had always emphasis on value of knowledge, and he promoted medical research also. At the time of conquest of Makkah the Holy prophet forgave those people who were able to teach the Muslim. He appreciated the people who were played an active participation in education. At that time madrasa and maktab was attached to the mosque where people got education.

To enlighten the appreciable behavior of Holy Prophet towards education M. Hamiuddin said;

"The Prophet entrusted young men with responsibilities, according to their capacities and allowed them the opportunities of specializing in one branch of learning or other". (History of Muslim education Vol. 1, p: 22).

For this purpose there is an example of Hazrat Zaid Bin Sabit who was specialist in arithmetic and also excelled in the law of inheritance. In the light of teachings of Islam, Muslim had learned with their heart and soul because it was an article of faith to them. Muslim has thought that acquiring knowledge and imparting of learning is one of their religious obligations.

Considering the importance of education Muslim tried their best to gained knowledge about each and every thing. Muslim's era in Spain is an example of this marvelous development of education; they made spectacular progress in developing educational institutions, great inventions in sciences patronized arts, and developed libraries rich in books. At that time only in Cordoba and Baghdad the libraries claim to have had over 400,000 books (McClellan \& Dorn 1999).

Muslim scientist discovers knowledge which derived from other civilizations like Greek, Indian, Chinese, and Persian, and they translated the knowledge in Arabic. They learned how to produce paper, and this effort made an easily available of books for all around the Spain. Communication became easier because Muslim empire united for education. Scholars were travelled to teach and share ideas (Haddad, F. S. 1993).Support of Muslim ruler was also an admirable because they appreciated the scholar who travelled Cordova from different countries, and scholars got big rewards form the ruler.

Muslim's contributions in Spain were a remarkable progress which had been paved the way to renaissance for Europe. During that period Muslim were practiced the teachings of Holy Quran and Holy Prophet. That's why in that period big scholars were produced by Muslims like Al Khwarizmi, Al Ghafiqi, Ibne- rushed Jabir Ibn Haiyan, and one of the famous Abu Ali al-Husain Ibn Abdullah Ibn Sina who is known by Avicenna (MazharulHaq, 1988).

Hence it is obvious that it was the teaching of Islam that pressed Muslim for gaining knowledge about each and every thing in this universe. Islam prefers that a literate person is better than illiterate. There had a lot of verses in Holy Quran where Allah impressed upon men that acquiring knowledge is really good for mankind. Holy Prophet also encouraged people for gaining knowledge and He appreciated those sahaba who had been able to read and write.That's why Muslim era in Spain was a golden age, because they followed the rules and principles of Islam. They did great advancements in education, inventions in sciences, and established Spain. 
But when they left the practices of Islam, they fell in luxuries, and turned their back to teaching of Islam, they got set on perilous path, and they lost all grace and glory.

\section{References:}

[1]. Haddad, F. S. (1993) Arab contribution to medicine.Bull. Soc. Liban. Hist. Med. 1, 21-33.

[2]. Ka'bah, Rifyal et al. n. d. Prophet Muhammad: Blessing for Mankind, Saudi Arabia: Alharamain Islamic Foundation.

[3]. King Abdul Aziz University (1977) First World Conference on Muslim Education. Makkah al-Mukarramah, Saudi Arabia: King Abdul Aziz University.

[4]. M. Hamiuddin Khan (1967) Vol. 1 pp 18-24. History of Muslim education, Academy of Educational Research All Pakistan.

[5]. MazharulHaq, A Short History of Muslim Spain (1988), first edition p 418

[6]. McClellan, J.E, \& Dorn, H. (1999).Science and technology in World History. Baltimore, MD: John Hopkins University Press. 